\title{
How do terrestrial plants access high molecular mass organic nitrogen, and why does it matter for soil organic matter stabilization?
}

\author{
Bartosz Adamczyk (D)
}

Received: 22 February 2021 / Accepted: 24 May 2021 / Published online: 10 June 2021

(C) The Author(s) 2021

\begin{abstract}
Although there is increasing awareness of the potential role of organic $\mathrm{N}$ compounds $(\mathrm{ON})$ in plant nutrition, its implications for soil organic matter (SOM) stabilization have hardly been discussed yet. The aim of this paper is therefore to gather the newest insights into plant use of high molecular mass organic $\mathrm{N}$, its effect on root growth and anatomy, and finally, to discuss the implications of plant use of organic $\mathrm{N}$ for SOM stabilization. I propose that modified root growth due to the uptake of $\mathrm{ON}$ provides greater root and root-associated microbe input, leading to enhanced SOM stabilization. Finally, I discuss the role of the proposed framework in different ecosystems, and I encourage future studies combining plant $\mathrm{N}$ nutrition and SOM stabilization.
\end{abstract}

Keywords $\mathrm{N}$ acquisition $\cdot \mathrm{N}$ cycle $\cdot$ Soil decomposition $\cdot$ Soil proteolysis

\section{Introduction}

Nitrogen $(\mathrm{N})$ is a major nutrient determining plant productivity and thus it exerts strong control on soil organic matter (SOM) formation as plant litter

Responsible Editor: Hans Lambers.

B. Adamczyk $(\bowtie)$

Natural Resources Institute Finland, PL 2, 00791 Helsinki,

Finland

e-mail: Bartosz.Adamczyk@luke.fi provides carbon (C) and N-rich input (Vitousek and Howarth 1991; Knicker 2011; Kicklighter et al. 2019). However, fossil fuel combustion and the intensive use of synthetic fertilizers have deteriorated the $\mathrm{N}$ cycle (Mulvaney et al. 2009; Suddick et al. 2012). The interlinked $\mathrm{C}$ cycle has therefore also been impaired, resulting in a decrease of $\mathrm{C}$ sequestration (Fung et al. 2005). Thus, solutions that counteract further deterioration of these cycles with a concomitant increase of SOM stabilization are urgently needed.

SOM is a mixture of mostly labile organic biomolecules derived from litter degradation forming supramolecular aggregates stabilized by biochemical recalcitrance and interactions, mineral adsorption, and physical inaccessibility (Simpson et al. 2002; Schmidt et al. 2011; Clarholm et al. 2015; Adamczyk et al. 2019b). The SOM nitrogen pool is mainly composed of proteins/peptides with amino sugars as a second important fraction (Schulten and Schnitzer 1997; Knicker 2011). Although the traditional paradigm includes only the soil inorganic $\mathrm{N}$ (IN) pool as directly available to plants, more recent studies point to the direct acquisition of organic $\mathrm{N}$ (ON) compounds, i.e. urea (Mérigout et al. 2008), quaternary ammonium compounds (Warren 2013), amino acids (Näsholm et al. 2009) and short peptides (Tegeder and Rentsch 2010; Soper et al. 2011). Corresponding transporters for these $\mathrm{N}$ forms have also been recognized (Breitkreuz et al. 1999; Williams and Miller 2001; Svennerstam et al. 2008; PaungfooLonhienne et al. 2009; Tegeder and Rentsch 2010; 
Perchlik et al. 2014; Ganeteg et al. 2017). Moreover, it has been suggested that plant roots can directly take up proteins (Paungfoo-Lonhienne et al. 2008), DNA (Paungfoo-Lonhienne et al. 2010a) or even whole microorganisms (Paungfoo-Lonhienne et al. 2008, 2010b; White et al. 2015, 2018). In addition, roots directly enhance soil proteolysis with rootderived proteases (Godlewski and Adamczyk 2007; Paungfoo-Lonhienne et al. 2008; Adamczyk et al. 2010b) and indirectly through rhizosphere priming (Cheng et al. 2013) (Fig. 1).

Taking up ON does not leave root growth and plant biomass allocation unaffected (Cambui et al. 2011). The uptake of ON potentially leads to higher root growth compared with IN (Paungfoo-Lonhienne et al. 2009; Rasmussen et al. 2014; Lonhienne et al. 2014a). Similarly, rhizosphere microbial biomass increases under ON fertilization compared to IN (Ikoyi et al. 2020; Tang et al. 2020; Peltoniemi et al. 2021). Given that roots and root-associated microbes are the main source of stable SOM (Clemmensen et al. 2013), enhanced root and microbial growth may increase SOM stabilization. It has recently been shown that plant roots increase soil ON pool, and interaction between root-derived compounds with fungal necromass leads to SOM stabilization (Adamczyk

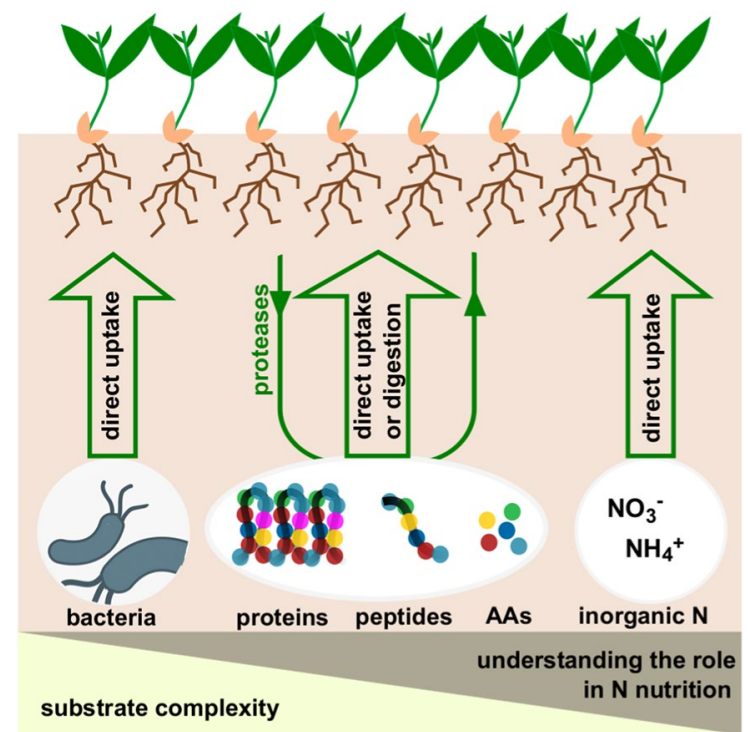

Fig. 1 Plant mechanisms for accessing soil nitrogen $(\mathrm{N})$ pools. AAs amino acids et al. 2019a, b). Hence, increased root growth could enhance the soil ON pool and SOM stabilization.

In this opinion paper, I aim to gather the newest information on the plant use of high molecular mass $\mathrm{ON}$ and its effect on root growth, anatomy, and SOM stabilization. I hypothesize that increased root growth due to the uptake of $\mathrm{ON}$ provides higher root and root-associated microbe inputs, leading to enhanced SOM stabilization. The paper is divided into three parts. The first gathers the newest insights into plant use of high molecular mass ON (via direct uptake and after depolymerization with root-derived proteases). The second provides information on how ON fertilizers affect root biomass and architecture. The third links the use of ON with SOM stabilization. Finally, I briefly analyze the impact of the proposed framework for different ecosystems and identify future directions.

\section{Plant mechanisms to access high molecular mass N sources}

There is now mounting evidence that $\mathrm{ON}$ can be directly used by plants. Groundbreaking work on the use of intact amino acids has been published (Näsholm et al. 2009), and uptake of quaternary ammonium compounds was demonstrated (Warren 2013). Moreover, more than one hundred organic $\mathrm{N}$ compounds were found to be exuded and taken up by wheat roots, including not only amino acids, but also polyamines, nucleobases and nucleosides (Warren 2015). The release of ON from the SOM supramolecular structure has recently been intensively studied (Clarholm et al. 2015; Keiluweit et al. 2015; Keiluweit and Kuyper 2020; Wang et al. 2020). Thus, here I will concentrate on plant access to SOMreleased high molecular mass $\mathrm{ON}$ via indirect and direct pathways.

Direct uptake of proteins and microorganisms

Although the direct uptake of whole intact proteins by Allium cepa, Hordeum vulgare, Solanum lycopersicum and Zea mays roots was already mentioned decades ago (Seear et al. 1968), this phenomenon has been waiting for long time to be proposed again. A study with Arabidopsis thaliana showed that roots take up intact proteins potentially via endocytosis 
(Paungfoo-Lonhienne et al. 2008). However, according to another study, minor damage of roots is necessary for protein uptake by Triticum aestivum (Rasmussen et al. 2015). In addition to whole proteins, it has been suggested that $A$. thaliana roots take up whole bacteria and yeast cells. As after uptake these microbes are degraded in root cells, this phenomenon has been called "rhizophagy" (Paungfoo-Lonhienne et al. 2010b). A further crucial step has been taken by White and co-workers, who proposed the term "rhizophagy cycle" and proved that it is widespread for vascular plants (White et al. 2018). In the rhizophagy cycle, microbes alternate between a root endophytic phase and a free-living soil phase, providing $\mathrm{N}$ for the plants (White et al. 2018). Studies on T. aestivum have suggested that the importance of soil microbe uptake to $\mathrm{N}$ cycling is relatively minor compared with fluxes of other forms of IN and ON (Hill et al. 2013). However, the available knowledge on the uptake of whole proteins and microorganisms is very limited. This means that an estimation of the role of such a process and its commonness in the plant kingdom remains impossible. The ability to take up whole proteins and microorganisms would constitute a potentially very efficient mechanism to access soil protein $\mathrm{N}$. Uptake of whole proteins could be increased under specific circumstances, like intensive $\mathrm{ON}$ fertilization and drying-rewetting events providing dead microbes and soil animals in the rhizosphere.

Indirect plant mechanisms to access protein $\mathrm{N}$

According to the traditional point of view, soil proteases originate only from free-living and plant-associated microbes. Trees form symbioses with ectomycorrhizal fungi (ECM), very efficient degraders of SOM able to secrete proteases (Smith et al. 2015; Brundrett and Tedersoo 2018). However, the vast majority of vascular plants, including agricultural species, form symbioses with arbuscular mycorrhizal fungi (AMF), which do not enhance soil proteolysis like ECM. Yet, AMF enhance plant ON acquisition via the ability to take up amino acids (Whiteside et al. 2012) and by increasing the volume of exploited soil (Lambers et al. 2019). Moreover, roots per se increase proteolysis (and thus, access to protein $\mathrm{N}$ ) via two routes. Roots enhance soil protein depolymerization by supporting rhizosphere microorganisms with easily available $\mathrm{C}$ sources, a phenomenon known as "rhizosphere priming effect" (Kuzyakov et al. 2000; Dijkstra et al. 2013; Cheng et al. 2013). Numerous plant species also enhance proteolysis directly via root-derived proteases, which include enzymes associated with the root surface (Chang and Bandurski 1964; Greenfield et al. 2020) and actively secreted by the roots (Godlewski and Adamczyk 2007) or root border cells (Brigham et al. 1995; Hawes et al. 2000, 2016; Miyasaka and Hawes 2001; Pan et al. 2004; Wen et al. 2007). Although root surface-associated enzymes are not secreted from roots, they may be even more important for soil decomposition than secreted ones. This is due to the spatial factor; increased proteolysis in the vicinity of the root potentially decreases competition with microorganisms for released $\mathrm{ON}$, prioritizing plant $\mathrm{N}$ uptake.

The knowledge of root-derived proteases and control over their activity is scarce, making yet the assessment of their role in the plant $\mathrm{N}$ budget challenging. An interesting approach would therefore be to compare mechanisms controlling the activity of root-derived proteases with those of root-derived acid phosphatases, as they share crucial similarities. For both enzymes, acid phosphatases and proteases derived from numerous crop species, the presence of organic forms of $\mathrm{N}$ or $\mathrm{P}$ in the culture media enhanced their activities (Yadav and Tarafdar 2001; Tarafdar and Claassen 2003; Adamczyk et al. 2008, 2010a), and the highest plant growth was obtained on media with inorganic and organic forms of $\mathrm{P}$ (Tarafdar and Claassen 2003) and N (Paungfoo-Lonhienne et al. 2008; Adamczyk and Godlewski 2010).

The greatest challenge here is to extrapolate laboratory axenic experiments to heterogeneous nonsterile conditions and assess the role of the abovementioned phenomena in plant $\mathrm{N}$ nutrition. The first attempts have already been made, and they show that the contribution of organic $\mathrm{N}$ to total $\mathrm{N}$ uptake by grassland plants (Kobresia humilis, Saussurea superba and Stipa aliena) at alpine meadows ranged between 13 and 35\% (Xu et al. 2006). Similarly, newly depolymerized high molecular ON contributed to the $\mathrm{N}$ nutrition of Z. mays, accounting for 20 to $30 \%$ of $\mathrm{N}$ uptake (Enggrob et al. 2019). The role of root-derived proteases from Z. mays and T. aestivum for soil proteolysis has also been assessed to be up to $20 \%$ of total soil proteolytic activity (Greenfield et al. 2020). 
The origin of the enzymes (microbes vs plant roots) could be identified with metaproteomics methods (Bastida et al. 2018). Future studies should consider heterogeneous ON sources, including recalcitrant soil ON pools (Adamczyk et al. 2019a, b) and hotspots of high molecular mass ON. In addition, spatial and temporal differences in $\mathrm{N}$ availability due to factors like drying-rewetting cycles (Warren 2013) or dead soil animals close to the roots should be taken into account. Moreover, as high molecular mass ON depolymerization is driven mainly by substrate availability and is not an enzyme-limited process this should also be assessed in future studies concerning plant $\mathrm{ON}$ use (Noll et al. 2019; Hu et al. 2020).

\section{Effect of different ON forms on root anatomy}

While ON uptake by plants is an increasingly recognized phenomenon, its effect on root growth, functioning, and anatomy is far less known. According to the current state of knowledge, plants growing on medium with $\mathrm{ON}$ allocate more biomass to the roots than these growing on IN; in addition they retain most of the ON taken up in the roots. This effect has been observed for low molecular mass ON (amino acids) (Cambui et al. 2011), but also for high molecular mass $\mathrm{ON}$ uptake by $A$. thaliana, T. aestivum, and Hakea actites (Paungfoo-Lonhienne et al. 2008; Rasmussen et al. 2014; Lonhienne et al. 2014a). The form of $\mathrm{N}$ taken up and plant $\mathrm{N}$ status affect not only root biomass, but also the root architecture, in a similar manner as $\mathrm{P}$ deficiency and the presence of organic P (OP). In P-deficient conditions, some plant species form "root clusters" including proteoid roots (in species from the Proteaceae and Fabaceae families, and many others) and dauciform roots (in some Cyperaceae species) (Shane and Lambers 2005; Nge et al. 2020). These roots secrete acid phosphatases in an "exudative burst" to decompose OP and exude carboxylates to suppress the adsorption of released Pi to mineral surfaces (Lambers et al. 2006, 2013; Playsted et al. 2006; Wang and Lambers 2020). Similarly, cluster roots are formed in response to $\mathrm{N}$-deficiency, but also in the presence of high molecular mass ON (Paungfoo-Lonhienne et al. 2009). The enrichment of the culture media with protein increased not only the formation of cluster roots of $H$. actities but also enhanced the expression of a putative peptide transporter, indicating the important role of cluster roots in ON uptake (Paungfoo-Lonhienne et al. 2009). Changes in root anatomy in the presence of proteins in the culture medium were also observed for plant species which do not form cluster roots. Protein in the culture medium turned the wheat (T. aestivum) root structure into a knob-like one (Rasmussen et al. 2014). The enhancement of root growth compared to IN addition was observed only for lower protein concentrations, while high protein concentrations inhibited root growth of T. aestivum, $H$. actites and A. thaliana (Paungfoo-Lonhienne et al. 2009; Rasmussen et al. 2014; Lonhienne et al. 2014a). Similarly, short peptides and amino acids in lower concentrations exert a positive effect on root growth compared to IN, and high amino acid concentrations lead to complete growth inhibition of Lobelia anceps and A. thaliana (Soper et al. 2011).

A logical assumption could be that increased root growth due to the uptake of ON decreases plant yield compared to IN fertilization. However, A. thaliana plants benefit from ON uptake in many ways, including an increase of resistance to root pathogens (Lonhienne et al. 2014b) and Glycine max increased absorption of water and nutrients (Teixeira et al. 2018). Available knowledge synthesized here therefore suggests that we can shape root growth and architecture via the proper management of $\mathrm{ON}$ fertilization.

\section{Linking access to high molecular mass ON with root anatomy and SOM stabilization}

Combining the ability of plants to use ON with its effect on root growth and architecture brings a new avenue for understanding root-driven SOM changes. Here, I propose a framework for integrating plant $\mathrm{ON}$ nutrition with SOM stabilization (Fig. 2). Increased root growth due to the uptake of ON leads to higher root and root-associated microbe inputs to the soil. Given that roots and associated microbes build up most of the stable SOM (Clemmensen et al. 2013; Liang et al. 2017), increased input from these sources should result in an increase of SOM build-up. However, a limitation with this approach is that rootderived inputs influence not only SOM stabilization, but also its formation and turnover (Clemmensen et al. 2013; Bastida et al. 2019; Sokol and Bradford 2019). The recently introduced framework of Rhizo-Engine 


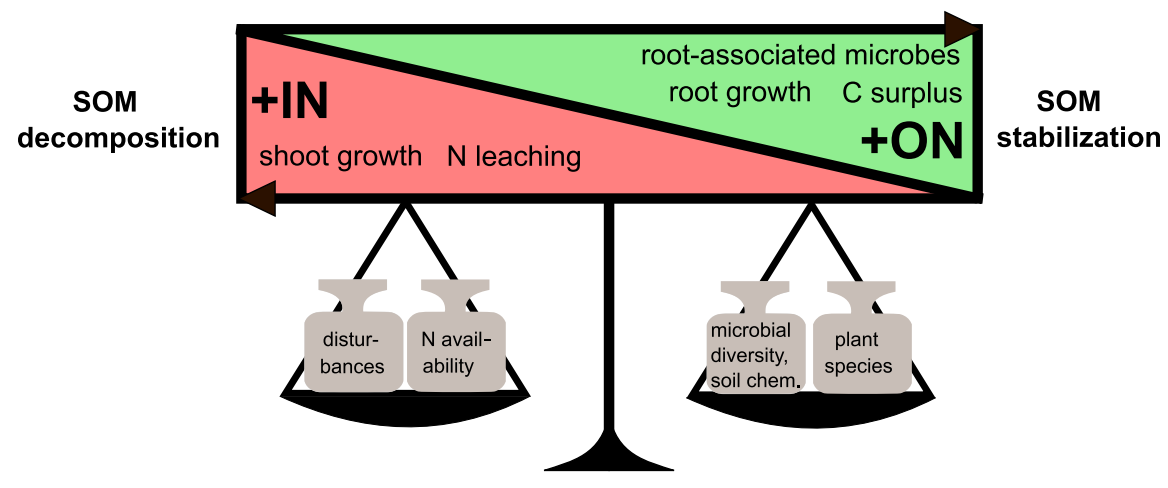

Fig. 2 Framework combining plant nitrogen (inorganic vs organic) uptake with SOM decomposition and stabilization. On the pink and green background effect of IN vs ON fertilization $(+\mathrm{IN}$ vs $+\mathrm{ON})$ are depicted. The balance between SOM

(Dijkstra et al. 2020) proposed four potential scenarios for root-driven soil organic $\mathrm{C}$ (SOC) dynamics. These include a) a destabilizing scenario, in which roots accelerate the formation of unprotected SOC and its decomposition, and b) a stabilizing scenario, in which roots accelerate the formation of protected SOC and accelerate the decomposition of unprotected SOC. Thus, how can we predict the effect of increased root growth due to plant ON uptake on SOM stabilization vs destabilization? The root-driven effect on SOM changes seems to be affected by the type of ecosystem and land use, $\mathrm{N}$ availability, climate conditions, disturbances, plant species, rhizosphere microorganisms, and soil chemistry (Fig. 2). Below, I will briefly discuss the implications of these factors for the framework proposed in this paper.

In low $\mathrm{N}$ availability ecosystems (e.g. boreal forests) with a dominant soil ON pool, plants partition more biomass to the roots (Chapin 1980; Levin et al. 1989), and ON uptake by plants and microbes provide a C surplus (Franklin et al. 2017). Thus, in line with the framework proposed in this paper $\mathrm{ON}$ uptake leads to SOM stabilization. In contrast, in high $\mathrm{N}$ availability ecosystems (e.g. agriculture with heavy IN fertilization), more biomass is partitioned to the shoots, the soil $\mathrm{N}$ pool is IN-richer, and there is no C surplus during $\mathrm{N}$ uptake (Clarholm 1997), SOM is therefore not/less stabilized. Thus, in high $\mathrm{N}$ availability ecosystems, ON fertilization could turn the soil $\mathrm{N}$ pool into a more $\mathrm{ON}$ orientated one with enhanced root growth and SOM build-up. In support of this, a long-term fertilization study of a $H$. vulgare-G. decomposition vs stabilization is affected also by factors presented as weights (in grey background). IN inorganic nitrogen, $O N$ organic nitrogen, SOM soil organic matter, soil chem. soil chemistry

$\max$ crop rotation showed that $\mathrm{ON}$ fertilization with manure increased SOC sequestration compared with IN fertilization (Guo et al. 2019).

SOM stabilization is affected by plant-soilmicrobe interactions including plant and microorganism biodiversity. Plants' preferences in taking up ON are species-specific (Liu et al. 2017), similarly as is the activity of root-derived proteases (Adamczyk and Godlewski 2010) and plant root-chemistry. All these factors may influence the effect on SOM stabilization (Coq et al. 2011; Sun et al. 2018; Adamczyk et al. 2019a; Hättenschwiler et al. 2019). Rhizosphere microorganisms affect SOM stabilization, and roots with mycorrhizal fungi are the source of the most stable soil C (Clemmensen et al. 2013). However, some ECM fungi, e.g. Cortinarius acutus, restrict SOM accumulation (Clemmensen et al. 2015; Kyaschenko et al. 2017; Lindahl et al. 2021), which underlines the need to understand the microbial community structure. Soil chemistry also affects SOM stabilization, e.g. soils rich in minerals bind more organic matter (Mikutta et al. 2006; Schmidt et al. 2011).

Climate change brings high temperatures, changes in precipitation, and $\mathrm{N}$ deposition, which adds more $\mathrm{N}$ to the ecosystem. The available experiments aiming to disentangle the effect of $\mathrm{N}$ deposition on $\mathrm{C}$ stabilization in forest ecosystems with low $\mathrm{N}$ availability mainly show an increase of $\mathrm{C}$ sequestration. The reason could be decelerated decomposition (Hyvönen et al. 2008; Janssens et al. 2010; Liu and Greaver 2010) or changes in SOM chemistry, i.e. more lignin derivatives and microbial $\mathrm{N}$ compounds 
(Hasegawa et al. 2021). Alternatively, such effect was explained by an increase of plant productivity leading to increased litter input (Forsmark et al. 2020). Atmospherically deposited IN in forest ecosystems with low $\mathrm{N}$ availability is rapidly immobilized (Sheng et al. 2014) by microbes, potentially providing ONrich microbial necromass for plants, mimicking ON fertilization in ecosystems with high $\mathrm{N}$ availability. However, in arable soils which are not so N-limited as forests (Sawada et al. 2015) meta-analysis showed that $\mathrm{N}$ deposition decreased microbial biomass and enhanced N leaching (Treseder 2008; Verma and Sagar 2020). Thus, the effect of $\mathrm{N}$ deposition depends on $\mathrm{N}$ availability of ecosystems.

Plants are thus able to access a wide set of $\mathrm{N}$ forms via multiple mechanisms which affects SOM stabilization. However, why do plants access ON? Why do they not wait for microbes to decompose ON to IN? First, the dominant soil $\mathrm{N}$ pool contains high molecular mass ON compounds (Clarholm et al. 2015; Knicker 2011), so the ability of plants to directly access this ON pool would be beneficial in $\mathrm{N}$ limiting ecosystems. Second, depolymerization is the crucial step in making high molecular mass $\mathrm{ON}$ available (Schimel and Bennett 2004; Jan et al. 2009), peptides and amino acids dominate as the products of enzymatic depolymerization of soil organic $\mathrm{N}$ (Warren 2021). As these peptides are taken up more quickly from soil than equivalent $\mathrm{N}$ monomers (amino acids) (Farrell et al. 2013), the plant's ability to compete for these $\mathrm{N}$ forms with soil microbes already at this stage is highly advantageous. Third, the carbon bonus of organic $\mathrm{N}$ uptake increases the plant $\mathrm{N}$ use efficiency (Franklin et al. 2017).

\section{Conclusions}

On the basis of the laboratory studies undertaken to date, we know that plants directly take up not only IN, but also ON, including amino acids, proteins, or even whole microorganisms. Moreover, plants directly increase soil proteolysis via root-derived proteases (root-surface associated or secreted from roots), and indirectly via rhizosphere priming.

Here, I propose that high molecular mass ON use increases root growth and turns the soil $\mathrm{N}$ pools to a more ON-oriented pathway, which results in enhanced SOM stabilization. The use of high molecular mass
ON by plants opens new avenues for climate-smart organic $\mathrm{N}$ fertilization, with concomitant SOM stabilization. However, the direction of root-driven SOM changes needs more study, taking into account plant species, rhizosphere microorganisms, and the soil physicochemistry. Given all the biological advantages of accessing high molecular mass $\mathrm{ON}$ and the need to decrease the use of IN fertilizers for mitigating climate change, work on this subject needs to continue, despite many challenges.

Funding Open access funding provided by Natural Resources Institute Finland (LUKE). The study was funded by the Academy of Finland (grant number 330136).

\section{Declarations}

Conflicts of interest/competing interests Not applicable

Open Access This article is licensed under a Creative Commons Attribution 4.0 International License, which permits use, sharing, adaptation, distribution and reproduction in any medium or format, as long as you give appropriate credit to the original author(s) and the source, provide a link to the Creative Commons licence, and indicate if changes were made. The images or other third party material in this article are included in the article's Creative Commons licence, unless indicated otherwise in a credit line to the material. If material is not included in the article's Creative Commons licence and your intended use is not permitted by statutory regulation or exceeds the permitted use, you will need to obtain permission directly from the copyright holder. To view a copy of this licence, visit http://creativecommons.org/licenses/by/4.0/.

\section{References}

Adamczyk B, Godlewski M (2010) Inter-specific variability in protein use by two vegetable crop species. Brazilian J Plant Physiol 22:171-176

Adamczyk B, Godlewski M, Zimny J, Zimny A (2008) Wheat (Triticum aestivum) seedlings secrete proteases from the roots and after protein addition, grow well on medium without inorganic nitrogen. Plant Biol 10:718-724

Adamczyk B, Godlewski M, Zimny J, Zimny A (2010a) Growth and protease secretion by roots of wheat seedlings cultivated on different nitrogen sources. Indian $\mathrm{j}$ Plant Physiol 15:150-153

Adamczyk B, Smolander A, Kitunen V, Godlewski M (2010b) Proteins as nitrogen source for plants: A short story about exudation of proteases by plant roots. Plant Signal Behav 5:817-819

Adamczyk B, Sietiö O-MM, Biasi C, Heinonsalo J (2019a) Interaction between tannins and fungal necromass 
stabilizes fungal residues in boreal forest soils. New Phytol 223:16-21. https://doi.org/10.1111/nph.15729

Adamczyk B, Sietiö O-MM, Straková P et al (2019b) Plant roots increase both decomposition and stable organic matter formation in boreal forest soil. Nat Commun 10:3982. https://doi.org/10.1038/s41467-019-11993-1

Bastida F, Jehmlich N, Torres IF, García C (2018) The extracellular metaproteome of soils under semiarid climate: A methodological comparison of extraction buffers. Sci Total Environ 619-620:707-711. https://doi.org/10. 1016/j.scitotenv.2017.11.134

Bastida F, García C, Fierer N et al (2019) Global ecological predictors of the soil priming effect. Nat Commun 10:3481. https://doi.org/10.1038/s41467-019-11472-7

Breitkreuz KE, Shelp BJ, Fischer WN et al (1999) Identification and characterization of GABA, proline and quaternary ammonium compound transporters from Arabidopsis thaliana. FEBS Lett 450:280-284. https://doi. org/10.1016/S0014-5793(99)00516-5

Brigham LA, Woo HH, Nicoll SM, Hawes MC (1995) Differential expression of proteins and mRNAs from border cells and root tips of pea. Plant Physiol 109:457-463. https://doi.org/10.1104/pp.109.2.457

Brundrett MC, Tedersoo L (2018) Evolutionary history of mycorrhizal symbioses and global host plant diversity. New Phytol 220:1108-1115. https://doi.org/10.1111/ nph.14976

Cambui CA, Svennerstam H, Gruffman L et al (2011) Patterns of plant biomass partitioning depend on Nitrogen source. PLoS ONE 6:e19211. https://doi.org/10.1371/ journal.pone.0019211

Chang CW, Bandurski RS (1964) Exocellular Enzymes of Corn Roots. Plant Physiol 39:60-64. https://doi.org/10. 1104/pp.39.1.60

Chapin FS (1980) The Mineral Nutrition of Wild Plants. Annu Rev Ecol Syst 11:223-260. https://doi.org/10. 1146/annurev.es.11.110180.001313

Cheng W, J. PW, A. GM, et al (2013) Synthesis and modeling perspectives of rhizosphere priming. New Phytol 201:31-44. https://doi.org/10.1111/nph.12440

Clarholm M (1997) The nitrogen problem. In: Xelikoff JT (ed) Ecotoxicology: responses, biomarkers and risk assessment, an OECD workshop. SOS Publications, Fair Heaven, pp 387-402

Clarholm M, Skyllberg U, Rosling A (2015) Organic acid induced release of nutrients from metal-stabilized soil organic matter - The unbutton model. Soil Biol Biochem 84:168-176

Clemmensen KE, Bahr A, Ovaskainen O et al (2013) Roots and associated fungi drive long-term carbon sequestration in boreal forest. Science (80- ) 340:1615-1618

Clemmensen KE, Finlay RD, Dahlberg A et al (2015) Carbon sequestration is related to mycorrhizal fungal community shifts during long-term succession in boreal forests. New Phytol 205:1525-1536

Coq S, Weigel J, Butenschoen O et al (2011) Litter composition rather than plant presence affects decomposition of tropical litter mixtures. Plant Soil 343:273-286. https:// doi.org/10.1007/s11104-011-0717-y
Dijkstra FA, Carrillo Y, Pendall E, Morgan JA (2013) Rhizosphere priming: a nutrient perspective. Front Microbiol 4:216. https://doi.org/10.3389/fmicb.2013.00216

Dijkstra FA, Zhu B, Cheng W (2020) Root effects on soil organic carbon: a double-edged sword. New Phytol. https://doi.org/10.1111/nph.17082

Enggrob KL, Jakobsen CM, Pedersen IF, Rasmussen J (2019) Newly depolymerized large organic N contributes directly to amino acid uptake in young maize plants. New Phytol 224:689-699. https://doi.org/10. 1111/nph.16070

Farrell M, Hill PW, Farrar J et al (2013) Oligopeptides represent a preferred source of organic $\mathrm{N}$ uptake: a global phenomenon? Ecosystems 16:133-145. https://doi.org/10. 1007/s10021-012-9601-8

Forsmark B, Nordin A, Maaroufi NI et al (2020) Low and High Nitrogen Deposition Rates in Northern Coniferous Forests Have Different Impacts on Aboveground Litter Production, Soil Respiration, and Soil Carbon Stocks. Ecosystems 23:1423-1436. https://doi.org/10.1007/ s10021-020-00478-8

Franklin O, Cambui CA, Gruffman L et al (2017) The carbon bonus of organic nitrogen enhances nitrogen use efficiency of plants. Plant Cell Environ 40:25-35. https:// doi.org/10.1111/pce. 12772

Fung IY, Doney SC, Lindsay K, John J (2005) Evolution of carbon sinks in a changing climate. Proc Natl Acad Sci U S A 102:11201 LP - 11206. https://doi.org/10.1073/ pnas.0504949102

Ganeteg U, Ahmad I, Jämtgård S et al (2017) Amino acid transporter mutants of Arabidopsis provides evidence that a non-mycorrhizal plant acquires organic nitrogen from agricultural soil. Plant Cell Environ 40:413-423. https://doi.org/10.1111/pce.12881

Godlewski M, Adamczyk B (2007) The ability of plants to secrete proteases by roots. Plant Physiol Biochem 45:657-664

Greenfield LM, Hill PW, Paterson E et al (2020) Do plants use root-derived proteases to promote the uptake of soil organic nitrogen? Plant Soil. https://doi.org/10.1007/ s11104-020-04719-6

Guo Z, Zhang Z, Zhou H et al (2019) The effect of 34-year continuous fertilization on the SOC physical fractions and its chemical composition in a Vertisol. Sci Rep 9:2505. https://doi.org/10.1038/s41598-019-38952-6

Hasegawa S, Marshall J, Sparrman T, Näsholm T (2021) Decadal nitrogen addition alters chemical composition of soil organic matter in a boreal forest. Geoderma 386:114906. https://doi.org/10.1016/j.geoderma.2020. 114906

Hättenschwiler S, Sun T, Coq S (2019) The chitin connection of polyphenols and its ecosystem consequences. New Phytol 223:5-7. https://doi.org/10.1111/nph.15840

Hawes MC, Gunawardena U, Miyasaka S, Zhao X (2000) The role of root border cells in plant defense. Trends Plant Sci 5:128-133

Hawes M, Allen C, Turgeon BG et al (2016) Root border cells and their role in plant defense. Annu Rev Phytopathol 54:143-161. https://doi.org/10.1146/annur ev-phyto-080615-100140 
Hill PW, Marsden KA, Jones DL (2013) How significant to plant $\mathrm{N}$ nutrition is the direct consumption of soil microbes by roots? New Phytol 199:948-955. https:// doi.org/10.1111/nph.12320

$\mathrm{Hu}$ Y, Zheng Q, Noll L et al (2020) Direct measurement of the in situ decomposition of microbial-derived soil organic matter. Soil Biol Biochem 141:107660. https:// doi.org/10.1016/j.soilbio.2019.107660

Hyvönen R, Persson T, Andersson S et al (2008) Impact of long-term nitrogen addition on carbon stocks in trees and soils in northern Europe. Biogeochemistry 89:121137. https://doi.org/10.1007/s10533-007-9121-3

Ikoyi I, Egeter B, Chaves C et al (2020) Responses of soil microbiota and nematodes to application of organic and inorganic fertilizers in grassland columns. Biol Fertil Soils 56:647-662. https://doi.org/10.1007/ s00374-020-01440-5

Jan MT, Roberts P, Tonheim SK, Jones DL (2009) Protein breakdown represents a major bottleneck in nitrogen cycling in grassland soils. Soil Biol Biochem 41:22722282. https://doi.org/10.1016/j.soilbio.2009.08.013

Janssens IA, Dieleman W, Luyssaert S et al (2010) Reduction of forest soil respiration in response to nitrogen deposition. Nat Geosci 3:315-322

Keiluweit M, Kuyper TW (2020) Proteins unbound - how ectomycorrhizal fungi can tap a vast reservoir of mineralassociated organic nitrogen. New Phytol 228:406-408. https://doi.org/10.1111/nph.16796

Keiluweit M, Bougoure JJ, Nico PS et al (2015) Mineral protection of soil carbon counteracted by root exudates. Nat Clim Chang 5:585-595. https://doi.org/10.1038/nclim ate 2580

Kicklighter DW, Melillo JM, Monier E et al (2019) Future nitrogen availability and its effect on carbon sequestration in Northern Eurasia. Nat Commun 10:3024. https:// doi.org/10.1038/s41467-019-10944-0

Knicker H (2011) Soil organic N - An under-rated player for C sequestration in soils? Soil Biol Biochem 43:1118-1129

Kuzyakov Y, Friedel JK, Stahr K (2000) Review of mechanisms and quantification of priming effects. Soil Biol Biochem 32:1485-1498. https://doi.org/10.1016/S00380717(00)00084-5

Kyaschenko J, Clemmensen KE, Hagenbo A et al (2017) Shift in fungal communities and associated enzyme activities along an age gradient of managed Pinus sylvestris stands. Isme J 11:863-875. https://doi.org/10.1038/ismej.2016. 184

Lambers H, Shane MW, Cramer MD et al (2006) Root structure and functioning for efficient acquisition of phosphorus: Matching morphological and physiological traits. Ann Bot 98:693-713

Lambers H, Ahmedi I, Berkowitz O et al (2013) Phosphorus nutrition of phosphorus-sensitive Australian native plants: Threats to plant communities in a global biodiversity hotspot. Conserv Physiol 1:10

Lambers H, Albornoz F, Arruda A et al (2019) Nutrient-acquisition strategies. In: A jewel in the crown of a global biodiversity. Kwongan Foundation and the Western Australian Naturalists' Club Inc, pp 227-248

Levin SA, Mooney HA, Field C (1989) The dependence of plant root: Shoot ratios on internal nitrogen concentration. Ann Bot 64:71-75. https://doi.org/10. 1093/oxfordjournals.aob.a087810

Liang C, Schimel JP, Jastrow JD (2017) The importance of anabolism in microbial control over soil carbon storage. Nat Microbiol 2:17105

Lindahl B, Kyaschenko J, Varenius K et al (2021) A group of ectomycorrhizal fungi restricts organic matter accumulation in boreal forest. Ecol Lett. https://doi.org/10.22541/ au.160440669.99375357/v1

Liu L, Greaver TL (2010) A global perspective on belowground carbon dynamics under nitrogen enrichment. Ecol Lett 13:819-828. https://doi.org/10.1111/j.14610248.2010.01482.x

Liu M, Li C, Xu X et al (2017) Organic and inorganic nitrogen uptake by 21 dominant tree species in temperate and tropical forests. Tree Physiol 37:1515-1526. https://doi. org/10.1093/treephys/tpx046

Lonhienne T, Trusov Y, Young A et al (2014a) Effects of externally supplied protein on root morphology and biomass allocation in Arabidopsis. Sci Rep 4:5055. https://doi. org/10.1038/srep05055

Lonhienne TGA, Trusov Y, Young A et al (2014b) The effect of protein supplied in the growth medium on plant pathogen resistance. Plant Signal Behav 9:e976159-e976159. https://doi.org/10.4161/15592324.2014.976159

Mahal NK, Osterholz WR, Miguez FE et al (2019) Nitrogen Fertilizer Suppresses Mineralization of Soil Organic Matter in Maize Agroecosystems. Front Ecol Evol 7:59. https://doi.org/10.3389/fevo.2019.00059

Mérigout P, Lelandais M, Bitton F et al (2008) Physiological and transcriptomic aspects of urea uptake and assimilation in Arabidopsis plants. Plant Physiol 147:1225-1238. https://doi.org/10.1104/pp.108.119339

Mikutta R, Kleber M, Torn MS, Jahn R (2006) Stabilization of soil organic matter: association with minerals or chemical recalcitrance? Biogeochemistry 77:25-56. https://doi. org/10.1007/s10533-005-0712-6

Miyasaka SC, Hawes MC (2001) Possible role of root border cells in detection and avoidance of aluminum toxicity. Plant Physiol 125:1978-1987. https://doi.org/10.1104/ pp.125.4.1978

Mulvaney R, Khan S, Ellsworth T (2009) Synthetic nitrogen fertilizers deplete soil nitrogen: a global dilemma for sustainable cereal production. J Environ Qual 38:22952314. https://doi.org/10.2134/jeq2008.0527

Näsholm T, Kielland K, Ganeteg U (2009) Uptake of organic nitrogen by plants. New Phytol 182:31-48

Nge F, Cambridge M, Ellsworth DS, et al (2020) Cluster roots are common in Daviesia and allies (Mirbelioids; Fabaceae). J Royal Soc Western Australia 103:111-118

Noll L, Zhang S, Zheng Q et al (2019) Wide-spread limitation of soil organic nitrogen transformations by substrate availability and not by extracellular enzyme content. Soil Biol Biochem 133:37-49. https://doi.org/10.1016/j.soilb io.2019.02.016

Pan JW, Ye D, Wang LL et al (2004) Root border cell development is a temperature-insensitive and Al-sensitive process in barley. Plant Cell Physiol 45:751-760. https://doi. org/10.1093/pcp/pch090

Paungfoo-Lonhienne C, Lonhienne TGA, Rentsch D et al (2008) Plants can use protein as a nitrogen source 
without assistance from other organisms. Proc Natl Acad Sci 105:4524-4529. https://doi.org/10.1073/pnas.07120 78105

Paungfoo-Lonhienne C, Schenk P, Lonhienne T et al (2009) Nitrogen affects cluster root formation and expression of putative peptide transporters. J Exp Bot 60:2665-2676. https://doi.org/10.1093/jxb/erp111

Paungfoo-Lonhienne C, Lonhienne TGA, Mudge SR et al (2010a) DNA is taken up by root hairs and pollen, and stimulates root and pollen tube growth. Plant Physiol 153:799-805. https://doi.org/10.1104/pp.110. 154963

Paungfoo-Lonhienne C, Rentsch D, Robatzek S et al (2010b) Turning the Table: Plants Consume Microbes as a Source of Nutrients. PLoS ONE 5:e11915

Peltoniemi K, Velmala S, Fritze $\mathrm{H}$ et al (2021) Long-term impacts of organic and conventional farming on the soil microbiome in boreal arable soil. Eur J Soil Biol 104:103314. https://doi.org/10.1016/j.ejsobi.2021.103314

Perchlik M, Foster J, Tegeder M (2014) Different and overlapping functions of Arabidopsis LHT6 and AAP1 transporters in root amino acid uptake. J Exp Bot 65:51935204. https://doi.org/10.1093/jxb/eru278

Playsted CWS, Johnston ME, Ramage CM et al (2006) Functional significance of dauciform roots: Exudation of carboxylates and acid phosphatase under phosphorus deficiency in Caustis blakei (Cyperaceae). New Phytol 170:491-500. https://doi.org/10.1111/j.1469-8137.2006. 01697.x

Rasmussen J, Gilroyed B, Reuter T et al (2014) Efficiency of protein as a nitrogen source for wheat and morphological changes in roots exposed to high protein concentrations. Can J Plant Sci 94:603-613. https://doi.org/10.4141/ CJPS2013-187

Rasmussen J, Gilroyed BH, Reuter T et al (2015) Protein can be taken up by damaged wheat roots and transported to the stem. J Plant Biol 58:1-7. https://doi.org/10.1007/ s12374-014-0258-z

Sawada K, Funakawa S, Toyota K, Kosaki T (2015) Potential nitrogen immobilization as influenced by available carbon in Japanese arable and forest soils. Soil Sci Plant Nutr 61:1-10. https://doi.org/10.1080/00380768.2015. 1075364

Schimel JP, Bennett J (2004) Nitrogen mineralization: challenges of a changing paradigm. Ecology 85:591-602. https://doi.org/10.1890/03-8002

Schmidt MWI, Torn MS, Abiven S et al (2011) Persistence of soil organic matter as an ecosystem property. Nature 478:49-56

Schulten H-R, Schnitzer M (1997) The chemistry of soil organic nitrogen: a review. Biol Fertil Soils 26:1-15

Seear J, Bradfute OE, McLaren AD (1968) Uptake of Proteins by Plant Roots. Physiol Plant 21:979-989. https://doi. org/10.1111/j.1399-3054.1968.tb07325.x

Shane M, Lambers H (2005) Cluster roots: a curiosity in context. Plant Soil 27:101-125. https://doi.org/10.1007/ s11104-004-2725-7

Sheng W, Yu G, Fang H et al (2014) Sinks for inorganic nitrogen deposition in forest ecosystems with low and high nitrogen deposition in china. PLoS ONE 9:e89322
Simpson AJ, Kingery WL, Hayes MH et al (2002) Molecular structures and associations of humic substances in the terrestrial environment. Naturwissenschaften 89:84-88. https://doi.org/10.1007/s00114-001-0293-8

Smith SE, Anderson IC, Smith FA (2015) Mycorrhizal associations and phosphorus acquisition: from cells to ecosystems. Annu Plant Rev 48:409-439

Sokol NW, Bradford MA (2019) Microbial formation of stable soil carbon is more efficient from belowground than aboveground input. Nat Geosci 12:46-53. https://doi.org/ 10.1038/s41561-018-0258-6

Soper F, Paungfoo-Lonhienne C, Brackin R et al (2011) Arabidopsis and Lobelia anceps access small peptides as a nitrogen source for growth. Funct Plant Biol 38:788-796. https://doi.org/10.1071/fp11077

Suddick E, Whitney P, Townsend A, Davidson E (2012) The role of nitrogen in climate change and the impacts of nitrogen-climate interactions in the United States: Foreword to thematic issue. Biogeochemistry 114:1-10. https://doi.org/10.1007/s10533-012-9795-z

Sun T, Hobbie SE, Berg B et al (2018) Contrasting dynamics and trait controls in first-order root compared with leaf litter decomposition. Proc Natl Acad Sci 115:1039210397. https://doi.org/10.1073/pnas.1716595115

Svennerstam H, Ganeteg U, Näsholm T (2008) Root uptake of cationic amino acids by Arabidopsis depends on functional expression of amino acid permease 5 . New Phytol 180:620-630. https://doi.org/10.1111/j.14698137.2008.02589.x

Tang H, Li C, Xiao X et al (2020) Effects of short-term manure nitrogen input on soil microbial community structure and diversity in a double-cropping paddy field of southern China. Sci Rep 10:13540. https://doi.org/ 10.1038/s41598-020-70612-y

Tarafdar JC, Claassen N (2003) Organic phosphorus utilization by wheat plants under sterile conditions. Biol Fertil Soils 39:25-29. https://doi.org/10.1007/ s00374-003-0671-9

Tegeder M, Rentsch D (2010) Uptake and partitioning of amino acids and peptides. Mol Plant 3:997-1011. https:// doi.org/10.1093/mp/ssq047

Teixeira W, Fagan E, Soares L et al (2018) Changes in root architecture after amino acid application in a soybean crop. J Agric Sci 11:325-334. https://doi.org/10.5539/ jas.v11n1p325

Treseder KK (2008) Nitrogen additions and microbial biomass: a meta-analysis of ecosystem studies. Ecol Lett 11:11111120. https://doi.org/10.1111/j.1461-0248.2008.01230.x

Verma P, Sagar R (2020) Effect of nitrogen (N) deposition on soil-N processes: a holistic approach. Sci Rep 10:10470. https://doi.org/10.1038/s41598-020-67368-w

Vitousek PM, Howarth RW (1991) Nitrogen limitation on land and in the sea: how can it occur? Biogeochemistry 13:87-115. https://doi.org/10.1007/BF00002772

Wang Y, Lambers H (2020) Root-released organic anions in response to low phosphorus availability: recent progress, challenges and future perspectives. Plant Soil 447:135156. https://doi.org/10.1007/s11104-019-03972-8

Wang T, Tian Z, Tunlid A, Persson P (2020) Nitrogen acquisition from mineral-associated proteins by an 
ectomycorrhizal fungus. New Phytol 228:697-711. https://doi.org/10.1111/nph.16596

Warren CR (2013) Quaternary ammonium compounds can be abundant in some soils and are taken up as intact molecules by plants. New Phytol 198:476-485. https://doi. org/10.1111/nph.12171

Warren CR (2015) Wheat roots efflux a diverse array of organic $\mathrm{N}$ compounds and are highly proficient at their recapture. Plant Soil 397:147-162. https://doi.org/10. 1007/s11104-015-2612-4

Warren C (2021) What are the products of enzymatic cleavage of organic N? Soil Biol Biochem 154:108152. https://doi. org/10.1016/j.soilbio.2021.108152

Wen F, Vanetten HD, Tsaprailis G, Hawes MC (2007) Extracellular proteins in pea root tip and border cell exudates. Plant Physiol 143:773-783. https://doi.org/10.1104/pp. 106.091637

White JF, Chen Q, Torres MS et al (2015) Collaboration between grass seedlings and rhizobacteria to scavenge organic nitrogen in soils. AoB Plants 7:6. https://doi.org/ 10.1093/aobpla/plu093

White J, Kingsley K, Verma S, Kowalski K (2018) Rhizophagy cycle: an oxidative process in plants for nutrient extraction from symbiotic microbes. Microorganisms 6:95. https://doi.org/10.3390/microorganisms6030095

Whiteside MD, Garcia MO, Treseder KK (2012) Amino acid uptake in arbuscular mycorrhizal plants. PLoS ONE 7:e47643

Williams LE, Miller AJ (2001) Transporters responsible for the uptake and partitioning of nitrogenous solutes. Annu Rev Plant Biol 52:659-688. https://doi.org/10.1146/annurev. arplant.52.1.659

Xu X, Ouyang H, Kuzyakov Y et al (2006) Significance of organic nitrogen acquisition for dominant plant species in an alpine meadow on the Tibet plateau, China. Plant Soil 285:221-231. https://doi.org/10.1007/ s11104-006-9007-5

Yadav R, Tarafdar J (2001) Influence of organic and inorganic phosphorus supply on the maximum secretion of acid phosphatase by plants. Biol Fertil Soils 34:140-143. https://doi.org/10.1007/s003740100376

Publisher's note Springer Nature remains neutral with regard to jurisdictional claims in published maps and institutional affiliations. 